\title{
Rivers and City Image of Banjarmasin - South Kalimantan
}

\author{
Parida Angriani \\ Doctoral Program, Department of Geography Education \\ UniversitasNegeri Malang \\ Malang, Indonesia \\ ridaangriani@gmail.com
}

\author{
Sumarmi, I. Nyoman Ruja, Syamsul Bachri \\ Faculty of Social Science UniversitasNegeri \\ Malang \\ Malang, Indonesia
}

\begin{abstract}
Rivers for most residents in Banjarmasin have some functions as water resources, transportation infrastructures, economic activities, places for interaction and socialization. From the existing 150 rivers, there are merely 102 rivers that are still worked. Many rivers have lost their functions as a result of erosion, waste, and sedimentation. From those facts, it needs an attempt to revive the functions of rivers in order to become the basis of city development in Banjarmasin. This research is intended to describe the attempts which had been done and have been done by the government concerning to the directions of Banjarmasin image recovery in city development concept especially in recovering the functions of rivers in Banjarmasin. This study uses a qualitative approach. Data collection techniques used are field surveys, interviews, literature studies and previous research's results. The result of the research shows that the attempts from the Government in Banjarmasin to recover its image in city development have been done normatively and formatively. Normatively through the implementation of various regulations related to river management, while formatively through the arrangement of riverbanks, optimizing the presence of rivers as a means of transportation and making floating markets as the identity of the region.
\end{abstract}

\section{Keywords-river, city image, Banjarmasin}

\section{INTRODUCTION}

Banjarmasin, the capital of South Kalimantan Province, grows and develops in the delta formed from the meeting of the Barito River and Martapura River. There are about 102 rivers, creeks, and canals that cross this city, so it is known as the River City [1]. The rivers have formed the character of Banjarmasin city both physically, ecologically, culturally, and economically. This confirms that between the group of people and the environment that is the river has formed a harmonious relationship [2]. River for most people Banjarmasin become an important part in life, covering physical aspect (quality and quantity of river physical); ecological (river ecosystem life), economy (transportation, floating market, fisherman, irrigation), and social (river community life) [3].

Although the image of Banjarmasin as the River City still remains attached, in fact the orientation of life of its people has undergone a more land oriented shift. The river is no longer the front yard of the settlement's main activity, but it has become a back yard, and this contributes greatly to the treatment of the river. The condition has changed the face of the river into irregular, dirty and even unhealthy. Other problems that are also increasingly complex is the increased pollution of river water due to household and industrial wastes, narrowing the river channel, siltation of the river, scouring river banks by the flow of water, until the loss of the river (dead) because it is covered by residential buildings. If this continues to be left, then the degradation and weakening of river functions and the elements forming the character of Banjarmasin city as River City will occur.

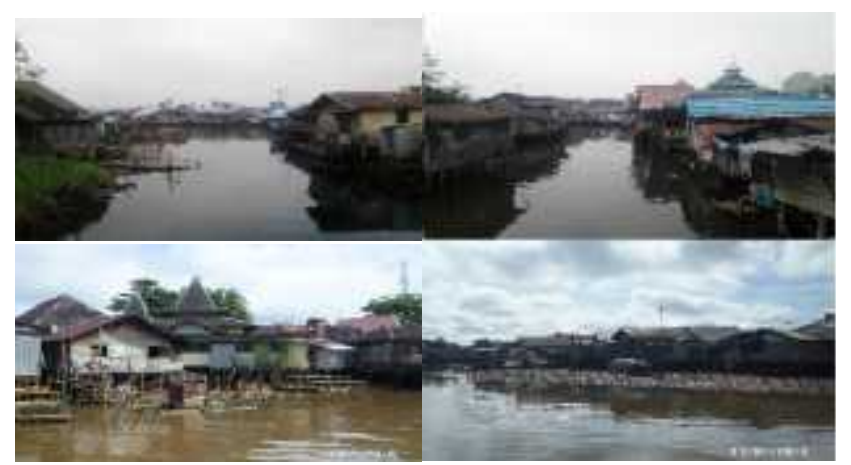

Fig 1.The impact of changes in the treatment of rivers (Photo by Angriani, 2016)

Currently, cities in Indonesia are focusing on developing thematic cities, such as green cities, heritage cities, and smart cities. The development of thematic city concept is not only an effort to showcase the character of the city, but also to keep the city character from various threats and degradation. The theme of the city is something very important because it helped shape the city's identity that distinguishes a city from another city. The identity or identity of this city can foster a sense of belonging and a sense of togetherness, even a sense of pride for the community to the city [4]. To realize the theme of the city does not stop until the physical order of the city, but must be rooted in the socio-economic life of the community, so that more sturdy survive and sustainable. 
Banjarmasin itself has also made various efforts to restore the image of the city, both done by the government and Banjarmasin own community. This study aims to describe the efforts that have been and are being done by the government associated with the direction of image improvement in Banjarmasin city development concept, especially in an effort to restore the function of the river in Banjarmasin.

\section{METHOD}

The method used in this research is descriptive qualitative. The data were collected based on the results of field surveys, documentation, and data from related agencies i.e. in the form of exposure reports of Water Resources and Drainage of Banjarmasin (DSDAD) in year 2016. Field survey conducted by exploring several rivers in the city of Banjarmasin by using klotok: Estuary of Barito River, Kuin River, Alalak River, Andai River, Jingah River and Martapura River. In addition, it also observes on the riverside area formed from the physical character or river ecology, as well as the economic and social life of the community. While the data derived from the DSDAD report is a description of some of the results that have been and are being done by the government in order to return the function of the river in the city of Banjarmasin.

\section{FINDINGS AND DISCUSSION}

\section{A. River Function}

Riversand the ridges are very rich in flora and fauna as well as a barometer of the ecological conditions of the area. A natural river can function as a natural aeration that will increase or maintain the oxygen content of river water [5]. In addition, the river also functions as: 1) Heritage: the river is an inheritance that needs to be preserved, and this should touch all areas of the city and the lives of citizens; 2) Community Resources: the river becomes a resource for a community, its opportunities and contribution are closely related to the quality of life of the people in the region; 3) Economic Development: the river provides economic opportunities in terms of urban regeneration, economic development, tourism, recreation, compatible land development; 4) Community Building: The river provides a unique opportunity in building the community, becoming a catalyst to involve the community in determining and investing in the future. 5) Water Quality: rivers have a very important value because they are related to biodiversity and must be protected to support natural and human ecosystems; and 6) Working River: rivers provide environmental services primarily associated with rainwater and wastewater flow points for residents [6]. Based on this, the utilization of the river in supporting human life must pay attention to environmental rules, for the sustainability of the river is maintained.

Based on the results of field surveys conducted in several places, such as Estuary Barito River, Kuin River, Alalak River, Sungai Andai, Jingah River and Martapura River. Some areas of the river have already changed function. The river is no longer an ecosystem environment that needs to be taken care of, but it has been converted into residential areas and places of business such as saw mill. Almost most of the residential buildings on the banks of the river stand above the river and take the river body, both on the left and right side of the river. This causes the width of the river body to be reduced.

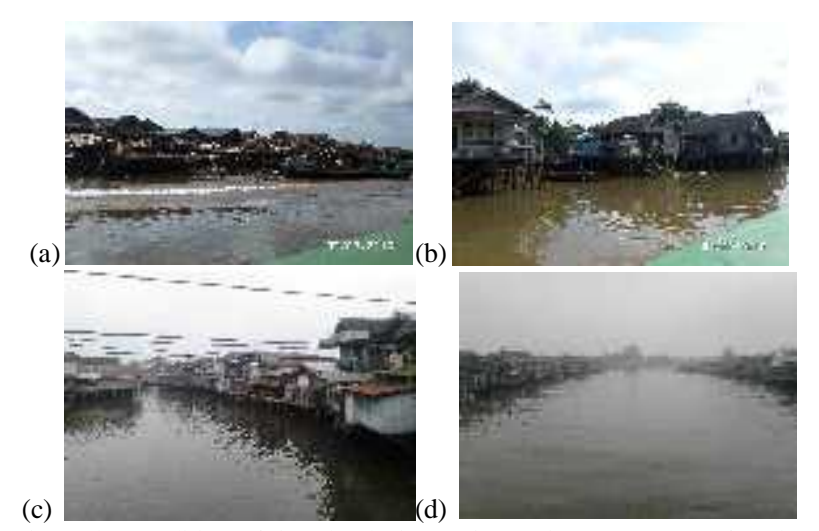

Fig 2.The condition of river banks in Banjarmasin, (a) Estuary of Barito River, (b) Kuin River, (c) Jingah River, (d) Martapura River. (Photo by Angriani, 2016)

On the one side, the pattern of river-side settlements is a cultural manifestation of Banjarmasin society that originally is river-oriented, but on the other side raises its own problems mainly related to laws and regulations about buildings built near the land and water (rivers), or partly on land and partially on water, or all parts above water [7].Seeing these conditions, various efforts have been made by the Government of Banjarmasin City to restore the function of the river, both ecologically and culturally. The effort continues until now through the river improvement program and river basin management. Normatively, it is carried out by applying various regulations related to river management, such as Government Regulation No. 38 year 2011 concerning River, Regulation of Minister of Public Works No.63 / PRT / 1993 on Border Line of River and River, Regulation of Minister of Public Works and People's Housing No.28 / PRT / M / 2015 on Stipulation of Riverbanks and Lake Border, Government Regulation No. 37 year 2012 on River Basin Management, Banjarmasin Local Regulation No. 2 year 2007 on River Management and Regional Regulation No. 31 year 2012 on Stipulation, Arrangement of River and River Boundary Utilization.

In addition to implementing the various regulations, the government also incorporated the concept of city-based river management on the concept of Spatial Plan (RTRW) structure. This is done through the stabilization of Barito River network function as a regional movement path, consolidation of Martapura River network function as a regional movement and movement path in Banjarmasin City, as well as stabilization of Kuin River network function, Alalak River and Kelayan River, as a movement path in Banjarmasin city[8].

While formative (technical), restore the function of the river is done by the arrangement of riverside area by taking into account the hydrological aspects and behavior of the river (ecological function). River banks were developed as public open spaces with riverwalk concept. Public access to the river 
as public property was opened wide. Existing trade and service areas that often cause conflict are arranged in an integrated manner with the concept of regional revitalization. The building built is technically adjusted, that is with the concept of house stage with a lightweight material. Optimizing the presence of rivers as a means of transportation to preserve the tradition of boating and making floating markets as regional identity.
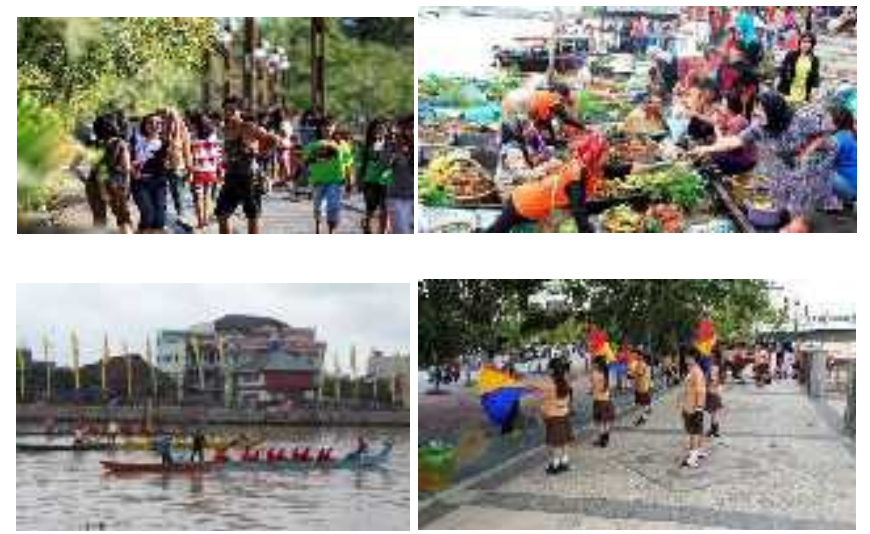

Fig 3.Arrangement of riverside area of Martapura River as public space (Photo by DSDAD of Banjarmasin, 2016).

Based on the results of interviews with the local government, restore the function of the river area has become the program of the Government of Banjarmasin City through the Department of Water Resources and Drainage (DSDAD). The program actually has been running for a long time, but with the Regional Regulation of Banjarmasin City No. 2 year 2007 on River Management program is increasingly improved. Started from 2008 and continues until now. The main activities are maintenance of large and small rivers, normalization of large and small rivers, construction and maintenance of drainage channels, revitalization and structuring of river banks (figures $4 \& 5$ ).

(a)
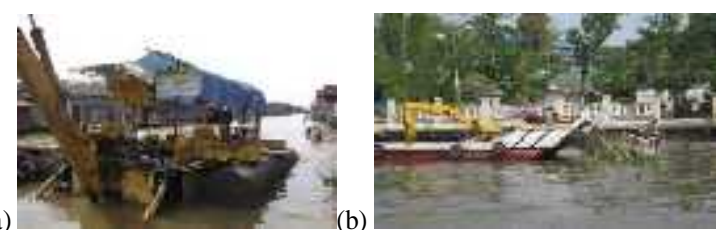

(c)

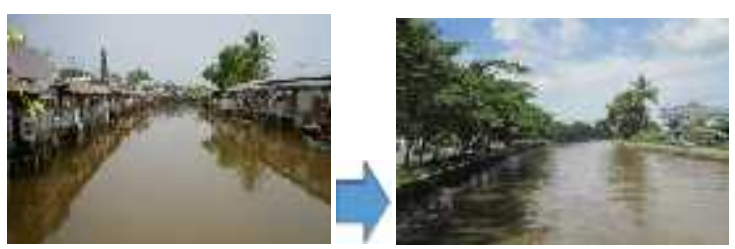

Fig 4. Maintenance of rivers and river normalization, (a) river dredging using Biyoko boats, (b) river cleansing using Sapu-Sapu boats, (c) normalization of JafriZam-Zam River (Photo by DSDAD of Banjarmasin, 2016).

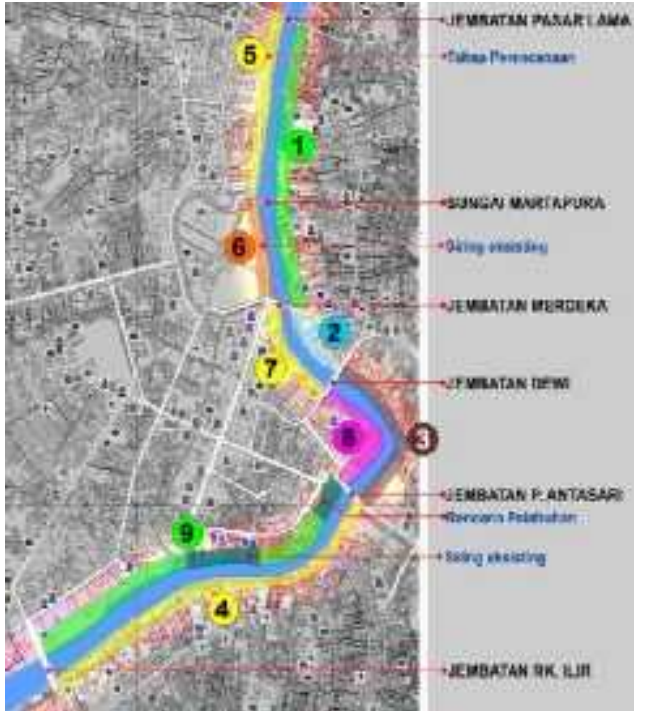

Fig 5. Map of activity of revitalization and structuring of river banks of the Martapura river cliff program in downtown Banjarmasin, (1) P. Tendean area, (2) P. Tendean area (front ofTempekong), (3) Baru River area, (4) RK Ilir area, (5) Sudirman area, (6) SiringSabilalMuhtadin area, (7) Pos Street area, (8) Ujung Murung area, (9) front of City Hall area (Source: DSDAD of Banjarmasin, 2016).

\section{B. City Image}

The image of the city very depends on the perception or way of looking at each person to a city [9][10]. The image of the city itself can be defined as a mental picture of a city formed from the biological rhythms of places and spaces that reflect the time (sense of time), which is grown from within deeply by the social, economic, and cultural activities of the people of the city itself [11][12]. From the description obtained three components that greatly affect the mental picture of people to an area, namely:

a) Identity as a potential that is read, meaning that people can understand the urban picture (identification of objects, differences between objects, things that can be known) or as identity that can differentiate with other cities;

b) Structure as a compiled potential, meaning that people can see urban patterns (object relations, object-object relations, visible patterns);

c) Meaning as imagined potential means one can understand urban space (the meaning of objects, the meaning of the subjects, the sense that can be experienced) through the symbolic, functional, emotional, historical, cultural, political [13][14].

Furthermore, there are five categories of elements that people use to structure the cognitive image of a number of places. The basic elements are:

a) Landmarks are striking signs of buildings or natural objects that are different from their surroundings and are owned only by the city;

b) Paths are paths connecting one place to another;

c) Nodes are nodes or intersections between paths, such as crossroads and forks; 
d) Edges is the boundary of the territory that distinguishes one region from another;

e) The districts are different homogeneous regions and other territories.

Of the five basic elements, landmark is the most important element in shaping the image of the city [15]. The more real the elements are in a city environment, the easier it is for people to arrange mental maps (better legality) [16].
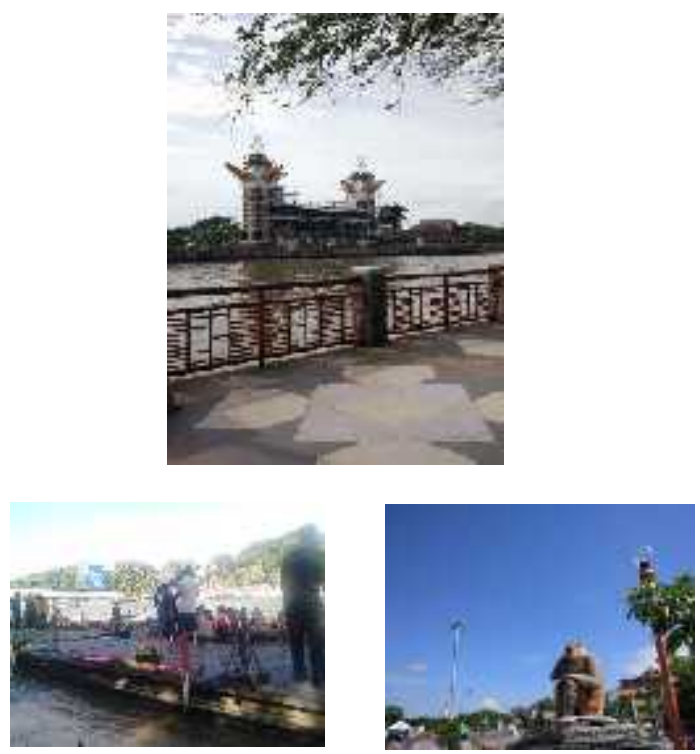

Fig 6. Some of the city landmarks of Banjarmasin: Menara Pandang, Floating Market, and Bekantan Statue in Siring Martapura River (Photo by Angriani, 2017).

Image can be formed by itself, but can also be made. As described earlier, it is similar to identity. An image can be intentionally created or inadvertently. An example of a deliberately formed image is if a region disseminates easily captured information into an image (whether factual or nonfactual) of its territory in order to be known to the public at large through communication media [17]. So what happens is the use of information obtained by an individual or society and serve as the basis for providing interpretation in the form of an image. Limitations and differences in incoming information allow an observer to interpret an area to be different from other observers.

Here are the results of interviews to some visitors in SiringMartapura River about the landmarks built on the banks of the Martapura River to establish the image of Banjarmasin as River City.

“... kalau liat view sungai di Banjarmasin (Sungai Martapura), paling pas ya di sini (Menara Pandang) soalnya bisa melihat pemandangan kota Banjarmasin dan Mesjid Sabilal Muhtadin, cuman kalau mau keatasharusnaik tangga dulu ..."

(Translated: if you want to see the view of the river in Banjarmasin (Martapura River), most right here (Menara Pandang) because it can see the view of the city of Banjarmasin and Sabilal Muhtadin Mosque, only if you want to go up the stairs first).
“... amun handak melihat kota Banjarmasin dariatas, baiknya keatas (Menara Pandang), pemandangan kelihatan luas parak Sungai Martapura ..." (Translated: if you want to see the city of Banjarmasin from above, preferably upwards (Menara Pandang), the view looks spacious near Martapura River).

“... sungainya nyaman, di siring rami gasan nongkrong, kalau di Singapura ada patung singa, mun di sini ada patung Bekantan ..."

(Translated: the river is beautiful, in Siring crowded for hanging out, if in Singapore there is a lion statue, in here there are Bekantan statue).

Meanwhile, the image formed by itself comes from the factual condition of the area, both physically and non-physically. The factual condition felt and experienced directly by the observer has a sharper impact on the formation of his image, because the environment he feels is an interconnected form between physical and human conditions.

\section{CONCLUSIONS}

The image of the city of Banjarmasin as the City of the River formed because the city is widely crossed by rivers. But along with the progress of development, the orientation of its people experience a more land oriented shift. The riverbanks are transformed into settlements or businesses. This raises some problems related to the existing river condition in Banjarmasin city, such as the increasing of river water pollution, narrowing of river channel, river sedimentation, until the loss of river (dead) because closed by housing building. If this continues to be left, then the degradation and weakening of river functions and the elements forming the character of Banjarmasin city as River City will occur. Therefore, various efforts have been made by the relevant government in order to restore the function of river in Banjarmasin city ecologically and culturally. Normatively done by applying various regulations, both Government Regulation and Local Regulation related to river management. While formatively done by doing the arrangement of river area by taking into account the hydrological aspects and behavior of the river (ecological function). The construction of new landmarks such as Menara Pandang and Bekantan Statue in SiringMartapura River increasingly solidify the image of Banjarmasin as River City. In addition, optimizing the existence of the river as a means of transportation for boating traditions remain sustainable and make the floating market as the identity of the region.

\section{REFERENCES}

[1] Water Resources and Drainage of Banjarmasin, Pembahasan program kerja Dinas Sumber Daya Air dan Drainase Kota Banjarmasin tahun anggaran 2016, Banjarmasin: Dinas Sumber Daya Air dan Drainase, 2016

[2] P. D. Buzarboruah, "Rivers and the assame folk life: a right relationship of man and nature, International Journal of Social Sciences", Arts and Humanities, 2(2), 2014, pp 33-45 
[3] P. Angriani, Sumarmi, I. N. Ruja, \&S. Bachri, The value of river for Banjarese community, South Kalimantan, Paper presented at the 4th International Conference Language, Society and Culture in Asian Contexts (LSCAC 2016), Malang, Indonesia, 2016.

[4] Banjarmasin Local Goverment, Workshop Kota Tematik, Membangun Kota Tematik Banjarmasin: Kota Sungai yang Berkelanjutan, Banjarmasin: Pemerintah Kota Banjarmasin, 2015.

[5] A. Maryono, Pengelolaan kawasan sempadan sungai dengan pendekatan integral: peraturan, kelembagaan, tata ruang, sosial, morfologi, ekologi, hidrologi, dan keteknikan, Yogyakarta: Gadjah Mada University Press, 2014

[6] London Community Foundation, Back to the river design competition, Retrieved from http://www.backtotheriver.ca/, 2015

[7] S. B. Utomo, andJ. Prijotomo, "Upgrading of traditional housing on waterfront areas: A case of legality and tradition", Informal Settlements and Affordable Housing, 2, Retrieved from http://www.irbnet.de/daten/iconda, 2009, pp 89-97

[8] P. U. Raditya, Waterfront city, Banjarmasin: Sebuah upaya inovatif pengembalian citra kota, Buletin Tata Ruang, 2011

[9] M. Rubin, C. Badea, J. Condie, Y. Mahfud,T. Morrison \&M. Peker, "Individual differences in collectivism predict city identification and city evaluation in Australian, French, and Turkish cities" Journal of Environmental Psychology, 50(Supplement C), 2017, pp 9-16.
[10] J. Savić, Sense(s) of the city: Cultural mapping in Porto, Portugal, City, Culture and Society. doi:https://doi.org/10.1016/j.ccs.2017.08.001, 2017.

[11] K. Lynch,The Image of the City: Harvard U.P.; Oxford U.P, 1960.

[12] Zahnd, M, Strategi Arsitektur 2: PERANCANGAN SISTEM KOTA SECARA TERPADU, Teori Perancangan Kota dan Penerapannya, Yogyakarta: Kanisius, 1999.

[13] A. D. Tohjiwa, "Citra pusat kota Depok berdasarkan peta kognitif pengamat", Jurnal Elektronik Gunadharma University, 8(2), 2009, pp 118

[14] S. D. Wulanningrum, "Elemen-elemen Pembentuk Kota yang Berpengaruh terhadap Citra Kota (Studi Kasus: Kota Lama Semarang). Jurnal Pembangunan Wilayah dan Kota", 10, 2014, pp 197

[15] T. Sakairi, M. Watanabe,K. Kamei,M. Ikawa,T. Kitamura, T. Izumi and Y.Nakatani, "A Study on the Location Search by Landmarks in Consideration of the Spatial Image", IFAC-PapersOnLine, 49(19), 2016, pp 361-366

[16] K. A. M. Hussain,andN. Ujang, " Visitors' Identification of Landmarks in the Historic District of Banda Hilir, Melaka, Malaysia", Procedia Social and Behavioral Sciences, 153(Supplement C), 2014, pp 689-699

[17] S.A. Al-ghamdi,F. Al-Harigi, "Rethinking Image of the City in the Information Age", Procedia Computer Science, 65(Supplement C), 2015, pp 734-743. 